\title{
SHOPPING ORIENTATION, STATUS CONSUMPTION AND IMPULSE BUYING OF GENERATION X AND Y IN PURCHASING FAST FASHION PRODUCTS
}

\author{
Widjojo Suprapto ${ }^{1 *}$, Ratih Indriyani ${ }^{2}$, Melyvia Santoso $^{3}$ \\ 1,2,3 Faculty of Business and Economics, Petra Christian University, Indonesia, \\ Email: 1joe.suprapto@gmail.com; ${ }^{2}$ ranytaa@petra.ac.id; ${ }^{3}$ melyvia07@gmail.com \\ * Corresponding author
}

\begin{abstract}
Generation cohorts have different tendencies in purchase behaviors, especially the Generation X and the Generation Y. Although the age gap between these two generation cohorts is not wide, the Generation X has distinctive purchase behaviors that are different from the Generation Y. In the fashion business, the Generation X consumers do not consider the brands in purchasing their clothes, but they calculate the benefits in buying a clothing product. However, the Generation Y consumers consider it as a part of their social status, therefore, they position themselves in the middle class or the upper class by what they wear. The aim of this research is to investigate the different purchase behaviors of the Generation $\mathrm{X}$ and $\mathrm{Y}$ in buying fast fashion products in Surabaya. The purchase behaviors are reflected through such variables as shopping orientation, status consumption, and impulse buying. As this is a quantitative research, the data are collected using questionnaires that are distributed to 100 respondents. The respondents are chosen using the purposive sampling technique. Then, the data are tested for the validity, reliability, normality, and homogeneity. To test the hypothesis, the independent samples t-test is used. The results show that the differences between the Generation X and the Generation Y are significant in their shopping orientation and impulse buying. However, there are no significant differences in the status consumptions.
\end{abstract}

Keywords: Generational cohort, shopping orientation, status consumption, impulse buying.

\begin{abstract}
Abstrak: Kohort generasi memiliki kecenderungan yang berbeda dalam perilaku pembelian, terutama Generasi X dan Generasi Y. Meskipun perbedaan usia antara kohort dua generasi ini tidak lebar, Generasi X memiliki perilaku pembelian khas yang berbeda dari Generasi Y. Dalam bisnis fashion, konsumen Generasi X tidak mempertimbangkan merek dalam membeli pakaian mereka, tetapi mereka menghitung manfaat dalam membeli produk pakaian. Namun, konsumen Generasi $Y$ menganggapnya sebagai bagian dari status sosial mereka, oleh karena itu, mereka memposisikan diri mereka di kelas menengah atau kelas atas dengan apa yang mereka kenakan. Tujuan dari penelitian ini adalah untuk menyelidiki berbagai perilaku pembelian Generasi X dan Y dalam membeli produk fast fashion di Surabaya. Perilaku pembelian tercermin melalui variabel seperti orientasi belanja, konsumsi status, dan pembelian impuls. Karena ini adalah penelitian kuantitatif, data dikumpulkan menggunakan kuesioner yang didistribusikan ke 100 responden. Responden dipilih menggunakan teknik purposive sampling. Kemudian, data diuji validitas, keandalan, normalitas, dan homogenitas. Untukmenguji hipotesis, sampel independen t-test digunakan. Hasil penelitian menunjukkan bahwa perbedaan antara Generasi X dan Generasi Y signifikan dalam orientasi belanja dan pembelian impuls mereka. Namun, tidak ada perbedaan yang signifikan dalam konsumsi status.
\end{abstract}

Kata kunci: Kohort generasi, orientasi belanja, konsumsi status, pembelian impuls.

\section{INTRODUCTION}

For decades, many marketers and business people have been using demographic and psychographic variables as their way to segment and target their markets (Kotler \& Armstrong, 2016). Although grouping the markets are very complex, a hybrid segmentation approach using a generation cohort is emerging as a substitute that is widely used by the marketers recently (Ting, Lim, de Run, Koh, \& Sahdan, 2018). Noble and Schewe (2003) indicate that cohorts can be a valuable segmentation technique for marketers because they describe groups of almost the same age individuals, who experience comparable external events during their late adolescent/early adulthood years.
Currently, the Generation $\mathrm{X}$ is dominating the business world. The majority of the baby boomer generation cohort members are retiring while the Generation Y (or the Millennials) are entering the workforce. Therefore, it is necessary to understand the characteristics of Generation $\mathrm{Y}$ that are significantly different from the previous cohort, Generation $\mathrm{X}$ (Reisenwitz \& Iyer, 2009). The Generation Xer are less materialistic as they value experience over acquisition; meanwhile the Generation Yers are very comfortable with digital technology, as a result, this generation will engage with brands in an entirely new way, such as with mobile or social media (Kotler \& Armstrong, 2016). In Indonesia, the members of the Generation $\mathrm{X}$ are current growing older with careers or 
business, and their disposable income also increases; meanwhile the members of the Generation $\mathrm{Y}$ are making their own money and starting to enjoy the benefits of their income. Generation X are those who were born between 1961 and 1980, while Generation $\mathrm{Y}$ are those who were born between 1091 and 2000 (Gurău, 2012).

Clothing has been considered as the primary human needs, along with food and shelter. Based on the Statistics Indonesia (Badan Pusat Statistik, 2018), the average household expenditures on clothing, shoes and sandals in big cities was $2,97 \%$, a slight decline from the previous year of $3.01 \%$, however, there is an increase of $6.43 \%$ in the total amount of money that is spent for clothing, shoes and sandals in 2017 (https://www.bps.go.id). Clothing industry has been evolving from the mass garment production and seasonal high fashion apparels to fast changing trendy fashion (Bhardwaj \& Fairhurst, 2010). The latter, fast fashion, is often used to depict clothing designs which go immediately from the catwalk to stores to fulfill new trends (Gabrielli, Baghi, \& Codeluppi, 2012). Fast fashion enables common consumers to buy trendy clothing at an affordable price, fast fashion is characterized by high impulse buying, low predictability, high volatility of market demand, and shorter life cycle (Bhardwaj \& Fairhurst, 2010).

Recently, clothes are not only limited to physiological needs, but also psychological needs, especially the needs for social status and sense of identity (Johnson, Lennon, \& Rudd, 2014). As the $21^{\text {st }}$ century social class is fading away, a person's social status may be determined by one's occupation, educational level, personal values, lifestyle choices, leisure time, social interaction patterns, and political leanings (Crane, 2000). For some people, fashion clothes still reflect their social status, as certain colors and motive designs are associated with higher ranks in society (Chairiyani, 2014). Fashion designers with their brands add the complexity of social status needs and sense of identity. For some others, wearing wellknown fashion designer brands and accessories is considered to have higher social status and is expected to be treated with better manner (Crane, 2000). According to Vinoth and Balaji (2015), the Generation $\mathrm{X}$ consumers in shopping for clothes do not prioritize brands that can be proud of to their surrounding social environment, but rather take into account the product benefits in buying clothes. Meanwhile, the Generation $\mathrm{Y}$ consumers use fashion apparels as a means of showing the social status and self-identity, so they try to place themselves in the middle and upper social status through their appearance (Valaei \& Nikhashemi, 2017).
The differences in shopping behavior among the Generation $\mathrm{X}$ and the Generation $\mathrm{Y}$ can also be examined by their shopping orientation and impulse buying. Shopping orientation refers to a consumer's approach to the act of shopping (Gehrt, Rajan, Shainesh, Czerwinski, \& O'Brien, 2012). The Generation $\mathrm{X}$ relies on the price and the quality of a product, meanwhile the Generation $\mathrm{Y}$ stresses more on the brand image of a product (Vinoth \& Balaji, 2015). For impulse buying, a research by Chang, Eckman, and Yan (2011) indicates that positive emotional responses of the consumers to the fashion store environment trigger significantly on impulse buying. Several researches have indicated that the Generation Y consumers tend to shop more impulsively than other generation cohorts (Bilgihan, 2016; Khan, Hui, Chen, \& Hoe, 2016; and Vinoth \& Balaji, 2015)

Since different generation cohorts expose different shopping behaviors, this study is going to investigate how different the Generation $\mathrm{X}$ and the Generation $\mathrm{Y}$ in buying the fast fashion apparels in Surabaya, Indonesia. Although Surabaya is the biggest city in Indonesia, the market segments in Surabaya have distinguish characteristics that are different from other metropolitan cities. Based on the shopping behavior, the market segments in Surabaya have similarities in high consideration on rebates, cashback, discounts, vouchers, sales promotion, and store membership to get the optimal shopping benefits in buying fashion apparels (Kwan, 2016)). Therefore, this research is investigating different behaviors in some variables of shopping activities by comparing the two potential generation cohorts in order to get a better understanding of each cohort's needs and wants.

\section{LITERATURE REVIEW AND HYPOTHESIS DEVELOPMENT}

\section{Generational Cohorts}

The concept of generation can be labelled as a group of individuals who are interrelated or have the same character, which can also be handled as a stage of life or a period of history (Yigit \& Aksay, 2015). In marketing, the theory of generational cohorts was proposed as a way to segment the population by year of birth, extending 20 to 25 years in length or as long as one birth group to be born (Lissitsa \& Kol, 2016). Differences in environmental and time factors cause people to have characteristics that can be mutually different so that their characteristics can be grouped according to the time period of their birth. According to Ting and de Run (2012), generational cohorts are groups of people born in the same time period, and going through similar experience of external 
happenings. These generational cohorts normally share similar ideas, values, attitudes, and beliefs shaped by external environments that occur during their adolescence (Noble \& Schewe, 2003). For this research, the Generation $\mathrm{X}$ is related to those who were born between 1961 to 1981, while the Generation Y is for those who were born between 1982 to 2000 (Parry \& Urwin, 2011).

\section{Shopping Orientation}

The concept of shopping orientation depicts shopping lifestyle or shopping style with the emphasis on shopping activities. Shopping orientation is defined as a distinguished shopping style which covers wishes, activities, and opinion about shopping processes (Seock, 2003). Jensen (2011) constructs five dimensions for shopping orientations, which consist of store enjoyment orientation, personalize orientation, time saving orientation, information orientation, and price saving orientation. Seock and Bailey (2008) conduct a factor analysis of clothing shopping orientations, and manage to identify seven constructs. This research adopts these seven constructs as the indicators to measure the shopping orientation. They are shopping enjoyment, brand consciousness, price consciousness, shopping confidence, convenience consciousness, brand or store loyalty, and in-home shopping tendency. Considering two different generation cohort buying behaviors, it is suspected that they have different preferences in their shopping orientation, therefore the hypothesis is constructed as follows:

$H_{l}$ : there is a significant difference in shopping orientation between the Generation X consumers and the Generation Y consumers in purchasing fast fashion products.

\section{Status Consumption}

A consumer purchases and consumes certain products or services in order to gain the status, regardless the social strata and income. According to Eastman and Liu (2012), status consumption is motivational processes in which individuals try to improve financial status through the use or consumption of products that become symbolic of status for individuals and their environment. Mai and Tambyah (2011) write status consumption as the consumption of goods and services that can display the status of the users or consumers. As a strong motivation for shopping, the status consumption has one measurement, an interest in consuming for status, which is derived into two indicators of conspicuous consumption and a desire for status (Eastman \& Liu, 2012). Considering two different generation cohort buying behaviors, it is suspected that they have different preferences in their status consumption, therefore the hypothesis is constructed as follows:

$\mathrm{H}_{2}$ : there is a significant difference in status consumption between the Generation X consumers and the Generation $\mathrm{Y}$ consumers in purchasing fast fashion products.

\section{Impulse Buying}

Impulse buying is an individual purchase that is done without any tendency to buy beforehand (unintended), done immediately (spontaneous), and without any deep thinking (unreflective) (Flight \& Scherle, 2013). Another research by Choudhary (2014) also confirms that an impulsive buying refers to obtaining products that are based more on spontaneous reactions rather than planning. A study by Badgaiyan, Verma, and Dixit (2016) manages to classify impulse buying factors into two dimensions, the cognitive and affective dimensions. The cognitive dimension of impulse buying refers to a concept of prudence, such as careful planning, in advance planning, cautious shopping; and the affective dimension relates to a concept of self-indulgence, such as enjoy spending money, indulge oneself, buy things for pleasure (Sharma, Sivakumaran, \& Marshall, 2011). Considering two different generation cohort buying behaviors, it is suspected that they are different in impulse buying tendency, therefore the hypothesis is constructed as follows:

$H_{3}$ : there is a significant difference in impulse buying between the Generation $X$ consumers and the Generation Y consumers in purchasing fast fashion products.

Baseon on the literature review and the three hypotheses above, the research framework is constructed as described in Picture 1.

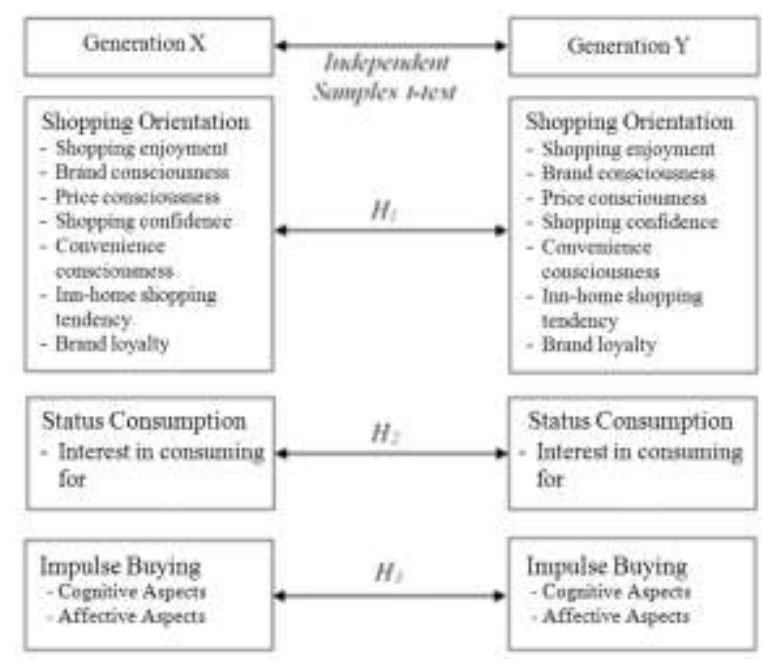

Picture 1. Research framework

Sources: Seock and Bailey, 2008; Eastman and Liu, 2012; Badgaiyan et al., 2016. 


\section{RESEARCH METHOD}

The aim of this research is to investigate the shopping differences among the Generation $\mathrm{X}$ and the Generation Y, therefore, this research falls into a comparative study. According to Azarian (2011), a comparative analysis refers to a research method that compares or contrasts the explicit variables in order to explore parallels and differences among the variables. Pickvance (2005) argues the two conventional methods of comparative analysis into four possibilities, explaining: similar phenomena by similar features, different phenomena by different features, similar phenomena by different features, and different phenomena by similar features. This research focuses on finding explanations from similar phenomena by different features. The phenomena of this research consist of shopping orientation, status consumption, and impulse buying.

Since this is a quantitative research, the data are collected from the populations, who are the Generation $\mathrm{X}$ and the Generation Y. Due to a large number of the population, the purposive sampling technique is constructed to select the samples, or a part of the represented population, for the data collection. As a nonprobability sampling technique, the purposive sampling technique is a way to choose samples with several certain conditions (Cooper \& Schindler, 2014). The criteria for the samples are between 19-37 years old for the Generation Y respondents and 38-53 years old for the Generation $\mathrm{X}$ respondents, residing in Surabaya, and buying the fast fashion products at least once a year. The number of samples in this research is 100 respondents, which is obtained using the formula by Lemeshow (Lemeshow, Hosmer, Klar, \& Lwanga, 1990), and therefore, 50 respondents for each generation.

The data are collected using questionnaires, which are distributed among the selected respondents in certain public places in Surabaya, such as malls and food courts. The questionnaire contains a set of written statements to measure the research indicators through the reply of the respondents. To reply each statement, the questionnaire adopts the Likert scale, from (1) strongly disagree to (5) strongly agree (Cooper \& Schindler, 2014). After the data collection, the data are analysed using these tests, the validity test, reliability test, descriptive statistic, normality test, homogeneity test, and independent sample $t$-test.

\section{FINDINGS}

The number of participants for this research is 100 respondents, consisting of 39 men and 61 women.
For the occupation, the Generation $\mathrm{X}$ respondents reveal that they are entrepreneurs, $26 \%$ of the respondents, and house wives, $20 \%$ of the respondents. The Generation Y respondents say that they are employees, $32 \%$ of the respondents, and entrepreneurs, $26 \%$ of the respondents. For the frequency in purchasing their fast fashion apparels, the Generation $\mathrm{X}$ respondents buy twice to three times a year, $50 \%$ of the respondents, and the Generation Y respondents buy four to five times a year, $48 \%$ of the respondents.

After the data are collected, a series of tests is conducted to examine the validity and reliability of the data. Table 1 . displays the validity test result. It can be inferred that all items are valid because the values of corrected item-total correlation are higher than $r_{\text {table }}$ of 0.195 .

Table 1. Validity Test

\begin{tabular}{|c|c|c|c|c|}
\hline Variables & Indicators & $\begin{array}{c}\text { Corrected } \\
\text { Item-Total } \\
\text { Correlation } \\
\end{array}$ & rtable & Remark \\
\hline Shopping & x1.1.01 & 0.61 & $>0.195$ & Valid \\
\hline \multirow[t]{20}{*}{ Orientation } & x1.1.02 & 0.60 & $>0.195$ & Valid \\
\hline & x1.1.03 & 0.71 & $>0.195$ & Valid \\
\hline & $\mathrm{x} 1.2 .01$ & 0.74 & $>0.195$ & Valid \\
\hline & $\mathrm{x} 1.2 .02$ & 0.65 & $>0.195$ & Valid \\
\hline & $\mathrm{x} 1.2 .03$ & 0.72 & $>0.195$ & Valid \\
\hline & x1.3.01 & 0.71 & $>0.195$ & Valid \\
\hline & x1.3.02 & 0.66 & $>0.195$ & Valid \\
\hline & x1.3.03 & 0.68 & $>0.195$ & Valid \\
\hline & x1.3.04 & 0.64 & $>0.195$ & Valid \\
\hline & x1.4.01 & 0.45 & $>0.195$ & Valid \\
\hline & x1.4.02 & 0.45 & $>0.195$ & Valid \\
\hline & x1.5.01 & 0.81 & $>0.195$ & Valid \\
\hline & x1.5.02 & 0.76 & $>0.195$ & Valid \\
\hline & x1.5.03 & 0.78 & $>0.195$ & Valid \\
\hline & x1.6.01 & 0.48 & $>0.195$ & Valid \\
\hline & x1.6.02 & 0.48 & $>0.195$ & Valid \\
\hline & x1.7.01 & 0.74 & $>0.195$ & Valid \\
\hline & $\mathrm{x} 1.7 .02$ & 0.69 & $>0.195$ & Valid \\
\hline & x1.7.03 & 0.71 & $>0.195$ & Valid \\
\hline & $\mathrm{x} 1.7 .04$ & 0.67 & $>0.195$ & Valid \\
\hline Status & x2.1.01 & 0.67 & $>0.195$ & Valid \\
\hline \multirow[t]{3}{*}{ Consumption } & $\mathrm{x} 2.1 .02$ & 0.71 & $>0.195$ & Valid \\
\hline & $\mathrm{x} 2.1 .03$ & 0.74 & $>0.195$ & Valid \\
\hline & $\mathrm{x} 2.1 .04$ & 0.66 & $>0.195$ & Valid \\
\hline \multirow[t]{11}{*}{ Impulse Buying } & x3.1.01 & 0.67 & $>0.195$ & Valid \\
\hline & x3.1.02 & 0.73 & $>0.195$ & Valid \\
\hline & x3.1.03 & 0.64 & $>0.195$ & Valid \\
\hline & x3.1.04 & 0.67 & $>0.195$ & Valid \\
\hline & x3.1.05 & 0.70 & $>0.195$ & Valid \\
\hline & x3.1.06 & 0.69 & $>0.195$ & Valid \\
\hline & x3.2.01 & 0.59 & $>0.195$ & Valid \\
\hline & x3.2.02 & 0.62 & $>0.195$ & Valid \\
\hline & x3.2.03 & 0.71 & $>0.195$ & Valid \\
\hline & x3.2.04 & 0.64 & $>0.195$ & Valid \\
\hline & $\mathrm{x} 3.2 .05$ & 0.66 & $>0.195$ & Valid \\
\hline
\end{tabular}

Table 2 shows the test result from the reliability test. It can be observed that all three variables in this 
research, shopping orientation, status consumption, and impulse buying, have the value of Cronbach's Alpha higher than 0.60 , therefore, all items are reliable to measure the variables.

Table 2. Reliability Test

\begin{tabular}{lccc}
\hline Variable & $\begin{array}{c}\text { Cronbach } \\
\text { Alpha }\end{array}$ & Coefficient & Remark \\
\hline Shopping orientation & 0.723 & $>0.60$ & Reliable \\
Status consumption & 0.852 & $>0.60$ & Reliable \\
Impulse buying & 0.919 & $>0.60$ & Reliable \\
\hline
\end{tabular}

Table 3 depicts the result of the descriptive statistic for each indicator. It shows that the mean of the shopping orientation variable for the Generation $\mathrm{X}$ is higher than the Generation Y. However, the means of the status consumption and the impulse buying for the Generation X are lower than the Generation Y.

The result of the normality test reveals the significant value above 0.05 , which indicates the data being normally distributed. For the homogeneity test, the result shows the significant value above 0.05 , so both sample groups have homogenous variants. Based on these test results, the data can be further processed for the independent $t$-test. To test the hypothesis, the independent sample $t$-test is performed. The results of the $t$-test can be observed in Table 4, which are based on the responding means of the Generation $\mathrm{X}$ and the Generation Y consumers toward shopping orientation, status consumption, and impulse buying in purchasing fast fashion products.

\section{DISCUSSION}

The results from the independent sample t-test reveal some significant differences on buying behaviors between the Generation $\mathrm{X}$ and the Generation $\mathrm{Y}$, which are shown by the higher mean from the responding Generation X than the Generation Y. With the $t$-calculated of $|-2.894|$, greater than the critical $t$ value of 1.980, there are significant differences statistically in shopping orientation among these generations, which are presented by the differences in shopping enjoyment, brand consciousness, price consciousness, shopping confidence, convenience consciousness, in-home shopping tendency, and brand loyalty. Based on the independent sample t-test, the mean from the responding Generation $X$ is lower than the Generation $\mathrm{Y}$ in their status consumption. Yet, the $t$-calculated of 1.333, smaller than the critical $t$-value of 1.980, suggests that there is no significant difference in status consumption while buying fast fashion products among the Generation $X$ and Y. Finally, the independent $t$-test of the impulse buying discloses the responding mean of the Generation X relatively lower than the Generation Y. The t-calculated of 4.598, greater than the critical $t$-value of 1.980 , indicates that there are significant differences in impulse buying for fast fashion products between the Generation $X$ and Generation Y, which are shown from the cognitive and affective aspects of their impulse buying patterns.

From the examined variables, there are significant differences on fast fashion buying behavior among the Generation $\mathrm{X}$ and the Generation $\mathrm{Y}$,

Table 3. Descriptive Statistic on Each Indicators

\begin{tabular}{|c|c|c|c|c|c|}
\hline \multirow{2}{*}{ Variable } & \multirow{2}{*}{ Indicator } & \multicolumn{2}{|c|}{ Generation X } & \multicolumn{2}{|c|}{ Generation Y } \\
\hline & & Mean & Remark & Mean & Remark \\
\hline \multirow[t]{8}{*}{ Shopping Orientation } & Total Mean for Shopping Enjoyment & 3.61 & agree & 3.91 & agree \\
\hline & Total Mean for Brand Consciousness & 3.29 & neutral & 3.55 & agree \\
\hline & Total Mean for Price Consciousness & 4.05 & agree & 3.50 & agree \\
\hline & Total Mean for Shopping Confidence & 3.87 & agree & 3.54 & agree \\
\hline & Total Mean for Convenience Consciousness & 3.48 & agree & 3.37 & neutral \\
\hline & Total Mean for In-Home Shopping Tendency & 3.51 & agree & 3.57 & agree \\
\hline & Total Mean for Brand Loyalty & 3.69 & agree & 3.52 & neutral \\
\hline & Total Mean for Shopping Orientation Variable & 3.66 & agree & 3.52 & agree \\
\hline Status Consumption & Total Mean for Status Consumption Variable & 3.62 & agree & 3.79 & agree \\
\hline \multirow[t]{3}{*}{ Impulse Buying } & Total Mean for Cognitive Aspect & 3.62 & agree & 4.10 & agree \\
\hline & Total Mean for Affective Aspect & 3.51 & agree & 3.95 & agree \\
\hline & Total Mean for Impulse Buying Variable & 3.57 & agree & 4.03 & agree \\
\hline
\end{tabular}

Tabel 4. Independent Samples $t$-test

\begin{tabular}{|c|c|c|c|c|c|c|}
\hline \multirow{2}{*}{ Variable } & & \multirow{2}{*}{$n$} & \multirow{2}{*}{ Mean } & \multirow{2}{*}{ Std. Deviation } & \multicolumn{2}{|c|}{ Independent Samples Test } \\
\hline & & & & & $t$ & Sig. \\
\hline \multirow[t]{2}{*}{ Shopping Orientation } & gen $X$ & 50 & 3.66 & 0.24 & -2.894 & 0.005 \\
\hline & gen $Y$ & 50 & 3.52 & 0.25 & & \\
\hline \multirow[t]{2}{*}{ Status Consumption } & gen $X$ & 50 & 3.62 & 0.54 & 1.333 & 0.185 \\
\hline & gen $Y$ & 50 & 3.79 & 0.73 & & \\
\hline \multirow[t]{2}{*}{ Impulse Buying } & gen $\mathrm{X}$ & 50 & 3.57 & 0.46 & 4.598 & 0.000 \\
\hline & gen $\mathrm{Y}$ & 50 & 4.03 & 0.54 & & \\
\hline
\end{tabular}


especially on the shopping enjoyment and impulse buying. The Generation X emphasizes more on the shopping orientation in buying the fast fashion products, as it is reflected by the highest mean of 3.66, meanwhile the Generation $\mathrm{Y}$ is more on impulse buying, with the highest mean of 4.03. For shopping enjoyment, the highest mean for the Generation $\mathrm{X}$ is on price consciousness, with the value of 4.05 , while for the Generation $\mathrm{Y}$ is on shopping enjoyment, with the value of 3.91. The price consciousness for the Generation X consumers to purchase fashion products tends to be stronger than then Generation Y consumers. This finding is also confirmed by Colucci and Scarpi (2013) who write the Generation Y having lower price consciousness than the Generation $X$ in purchasing goods. Vinoth and Balaji (2015) also support the finding by claiming that the Generation X considers more on the price while purchasing products than the Generation Y. The Generation X is more rational in considering price and calculating the benefits gained from the price of the products, while the Generation Y focuses more on the fashion trend and brand popularity (Lissitsa \& Kol, 2016). Meanwhile, the data also reveal that shopping enjoyment among the Generation Y relies on shopping excitement in buying fast fashion products, while for the Generation $\mathrm{X}$ is for releasing stress release while shopping fast fashion products. The shopping enjoyment of the Generation Y is supported by Petra's research in which she mentions the Generation Y enjoying shopping more significantly than other generation cohorts (2016). For the Generation X, shopping enjoyment is to reduce stress, as described by Kicheva (2017), that the Generation X seeks life-work balance by using shopping activities to balance daily routine.

Another variable that shows significant differences in purchasing fast fashion products is the impulse buying. The mean of impulse buying for the Generation Y is higher than the Generation X. This indicates that the Generation $\mathrm{Y}$ consumers tend to do unplanned purchases on fast fashion products than the Generation $\mathrm{X}$, as the Generation $\mathrm{Y}$ is easily influenced by the advertisement (Vinoth \& Balaji, 2015). Khan et al. (2016) also state that the Generation Y tends to be more impulsive in buying clothes compared to other generation cohorts. Having lower price consciousness and high impulsive buying behavior, the generation $\mathrm{Y}$ is often labeled as the consumptive generation (Ordun, 2015). As the Generation Y purchases fast fashion products impulsively or without prior planning, the Generation $\mathrm{X}$ considers buying fast fashion products as an unintentional purchase. Besides, the Generation Y consumers buy fast fashion products based on their likes and dislikes, while the Generation X consumers use their thorough considerations in buying any fast fashion products. This finding is similar to a research by Bilgihan (2016), who states the Generation Y as the most emotional consumers compared to other generation cohorts, which triggers the impulse buying.

Interestingly, based on the result of the independent sample $t$-test, there are no differences between the Generation $\mathrm{X}$ and the Generation $\mathrm{Y}$ in their status consumption while buying fast fashion products. Although the means of the Generation $\mathrm{X}$ and $\mathrm{Y}$ are different in their status consumptions, the differences are not significant. This finding is similar to a research of Eastman and Liu (2012), which suggests the status consumption of the Generation Y consumers being higher than the Generation $X$. The mean of the Generation $X$ for the status consumption is 3.62 , which is lower than the mean of the Generation Y of 3.79. The result of this research is similar to a research by Ordun (2015) which reveals the Generation Y consumers' stronger social status consideration in buying fast fashion products than the Generation $\mathrm{X}$ consumers. The Generation $\mathrm{X}$ considers the impacts after buying the fast fashion products, while the Generation Y tends to look at the social status as the orientation before buying the products. In the end, both generation cohorts relate the fast fashion products with their social status.

\section{CONCLUSION}

The results of the independent t-test prove that there are some significant differences on shopping behaviors among the Generation X and the Generation Y. The first hypothesis is accepted, stating that there is a significant difference in their shopping orientation in purchasing fast fashion products. The third hypothesis is also accepted, stating that there are some significant differences in their impulse buying in purchasing fast fashion products. However, the second hypothesis is rejected, as there is no significant difference in their status consumption in purchasing fast fashion products.

This research imposes some limitations as the numbers of respondents are relatively smaller than the total population. Besides, each city and region have some distinguished purchase behaviors that may affect the purchase intentions and purchase decision. The fast fashion products for this research covers limited brand names, such as H\&M, Zara, and Mango, that are easily accessible for the Surabaya markets. The findings of this research are expected to help marketing departments set up their strategies to reach these generation cohorts as they need different marketing approaches. The majority of the Generation $\mathrm{X}$ consumers is more price conscious, meanwhile the Generation $\mathrm{Y}$ is more impulsive in buying fast fashion products. 


\section{REFERENSES}

Azarian, R. (2011) Potentials and limitations of comparative method in social science. International Journal of Humanities and Social Science, 1(4), 113-125.

Badan Pusat Statistik. (2018). Rata-rata pengeluaran per kapita sebulan menurut kelompok barang (rupiah), 2013-2017. Retrieved from https://www. bps.go.id/statictable/2014/12/18/966/rata-ratapengeluaran-per-kapita-sebulan-menurut-kelompok-barang-rupiah-2013-2017.html.

Badgaiyan, A. J., Verma, A., \& Dixit, S. (2016). Impulsive buying tendency: Measuring important relationships with a new perspective and an indigenous scale. IIMB Management Review, 28, 186-199.

Bhardwaj, V., \& Fairhurst, A. (2010) Fast fashion: Response to changes in the fashion industry. The International Review of Retail, Distribution and Consumer Research, 20(1) 165-173.

Bilgihan, A. (2016). Gen y customer loyalty in online shopping: An integrated model of trust, user experience and branding. Computers in Human Behavior, 61, 103-113.

Chairiyani, R. P. (2014) Semiotika batik larangan di Yogyakarta. Humaniora, 5(2), 1177-1186.

Chang, H. J., Eckman, M., \& Yan, R. N. (2011) Application of the stimulus-organism-response model to the retail environment: The role of hedonic motivation in impulse buying behavior. The International Review of Retail, Distribution and Consumer Research, 21(3), 233-249.

Choudhary, S. (2014). Study of impulse buying behaviour of consumers. International Journal of Advances Research in Computer Science and Management Studies, 2(9), 1-4.

Colucci, M., \& Scarpi, D. (2013) Generation y: Evidences from the fast-fashion market and implications for targeting. Journal of Business Theory and Practice, 1(1), 1-7.

Cooper, D. R., \& Schindler, P. S. (2014) Business research method. New York, NY: McGraw-Hill.

Crane, D. (2000) Fashion and its social agendas: Class, gender, and identity in clothing. Chicago, IL: The University of Chicago Press.

Eastman, J. K., \& Liu, J. (2012) The impact of generational cohorts on status consumption: An exploratory look at generational cohort and demographics on status consumption. Journal of Consumer Marketing, 29(2), 93-102.

Flight, R. L., \& Scherle, J. (2013) Shopping context and the impulsive and compulsive buyer. Atlantic Marketing Journal, 2(2), 54-68.
Gabrielli, V., Baghi, I., \& Codeluppi, V. (2012) Consumption practices of fast fashion products: A consumer-based approach. Journal of Fashion Marketing and Management, 17(2), 206-224.

Gehrt, K. C., Rajan, M. N., Shainesh, G., Czerwinski, D., \& O'Brien, M. (2012) Emergence of online shopping in India: Shopping orientation segments. International Journal of Retail \& Distribution Management, 40(10), 742-758.

Gurău, C. (2012) A life-stage analysis of consumer loyalty profile: Comparing generation $\mathrm{x}$ and millennial consumers. Journal of Consumer Marketing, 29(2), 103-133.

Jensen, J. M. (2012) Shopping orientation and online travel shopping: the role of travel experience. International Journal of Tourism Research, 14(1), 56-70.

Johnson, K., Lennon, S. J., \& Rudd, N. (2014) Dress, body and self: Research in the social psychology of dress. Fashion and Textiles, 1(20), 1-24.

Khan, N., Hui, L. H., Chen, T. B., \& Hoe, H. Y. (2016). Impulse buying behaviour of generation $\mathrm{y}$ in fashion retail. International Journal of Business and Management, 11(1), 144-151.

Kicheva, T. (2017). Management of employees from different generations - Challenge for Bulgarian managers and $\mathrm{HR}$ professionals. Economic Alternatives, 1, 103-121.

Kotler, P., \& Armstrong, G. (2016) Principles of marketing. Global Edition $-16^{\text {th }}$ Edition. Essex: Pearson Education Limited.

Kwan. O. G. (2016) Pengaruh sales promotion dan store atmosphere terhadap impulse buying dengan positive emotion sebagai variable intervening pada Planet Sport Tunjungan Plaza Surabaya. Jurnal Manajemen Pemasaran, 10(1), 27-34.

Lemeshow, S., Hosmer Jr., D. W., Klar, J., \& Lwanga, S. K. (1990). Adequacy of sample size in health studies. West Sussex, England: John Wiley \& Sons Ltd.

Lissitsa, S., \& Kol, O. (2016). Generation x vs. generation $\mathrm{y}$ - A decade of online shopping. Journal of Retailing and Consumer Services, 31 , 304-312.

Mai, N. T. T., \& Tambyah, S. K. (2011). Antecedents and consequences of status consumption among urban Vietnamese consumers. Organizations and Markets in Emerging Economies, 2(1), 75-98.

Noble, S. M., \& Schewe, C. D. (2003) Cohort segmentation: An exploration of its validity. Journal of Business Research, 56, 979-987.

Ordun, G. (2015). Millenial (gen y) consumer behavior, their shopping preferences and perceptual maps associated with brand loyalty. Canadian Social Science, 11(4), 40-55. 
Parry, E., \& Urwin, P. (2011) Generational differences in work values: A review of theory and evidence. International Journal of Management Reviews, 13(1), 79-96.

Petra, K. K. (2016). Generation y attitudes towards shopping: A comparison of the Czech Republic and Slovakia. Journal of Competitiveness, 8(1), $38-54$

Pickvance, C. (2005) The four varieties of comparative analysis: The case of environmental regulation. In National centre for research methods and ESRC symposium on small and large-n comparative solutions, September 22-23 2005, University of Sussex, Brighton. Unpublished. Retrieved April 1, 2019, from http://eprints.ncrm.ac.uk/57/.

Reisenwitz, T., \& Iyer, R. (2009) Differences in generation $\mathrm{x}$ and generation $\mathrm{y}$ : Implications for the organization and marketers. The Marketing Management Journal, 19(2), 91-103.

Seock, Y. K. (2003). Analysis of clothing websites for young consumer retention based on a model of customer relationship management via the internet. Unpublished dissertation, Virginia Polytechnic Institute and State University.

Seock, Y. K., \& Bailey, L. R. (2008). The influence of college students' shopping orientations and gender differences on online information searches and purchase behaviors. International Journal of Consumer Studies, 32(2), 113-121.
Sharma, P., Sivakumaran, B., \& Marshall, R. (2011) Deliberate self-indulgence versus involuntary loss of self-control: Toward a robust crosscultural consumer impulsiveness scale. Journal of International Consumer Marketing, 23(3-4), 229-245.

Ting, H., \& de Run, E. C. (2012). Generations x and y attitude towards controversial advertising. Asian Journal of Business Research, 2(2), 24-39.

Ting, H., Lim, T. Y., de Run, E. C., Koh, H., \& Sahdan, M. (2018) Are we baby boomers, gen $x$ and gen $\mathrm{y}$ ? A qualitative inquiry into generation cohorts in Malaysia. Kasetsart Journal of Social Sciences, 39(1), 109-115.

Valaei N., \& Nikhashemi, S. R. (2017) Generation y consumers' buying behaviour in fashion apparel industry: A moderation analysis. Journal of Fashion Marketing and Management: An international journal, 21(4), 523-543.

Vinoth, S. \& Balaji, S. G. (2015). Changing consumer behviour between generation $\mathrm{x}$ and generation $\mathrm{y}$ on e-tailing (online shopping) - An empirical study. International Journal of Business and Administration Research Review, 2(II), 212-217.

Yigit, S., \& Aksay, K. (2015). A comparison between generation $\mathrm{x}$ and generation $\mathrm{y}$ in terms of individual innovativeness behavior: The case of Turkish health professionals. International Journal of Business Administration, 6(2), 106-117. 